\title{
KALIMAT IMPERATIF DALAM BAHASA LISAN MASYARAKAT DAYAK DEAH
}

\author{
Isna Kasmilawati dan Lili Agustina
}

\author{
STKIP PGRI Banjarmasin \\ Jalan Sultan Adam Komplek H. Iyus, No. 18 RT. 23 Banjarmasin, \\ Kalimantan Selatan, Kode pos 70121 \\ email: Isna_hafiz@Stkipbjm.ac.id dan lili.agustina0911@gmail.com
}

\begin{abstract}
ABSTRAK
Kalimat imperatif dalam bahasa Dayak Deah sangat beragam jenisnya, bisa saja berisi kalimat perintah yang keras dan kasar, dan bisa juga berupa kalimat perintah dengan permohonan yang santun dan halus.Dalam kehidupan sehari-hari, masyarakat Dayak Deah sering menggunakan kalimat perintah baik di rumah, sekolah atau lingkungan masyarakat, yang bersifat ajakan, larangan atau permohonan.

Penelitian bertujuan untuk mendeskripsikan kalimat perintah dalam bahasa lisan Dayak Deah.Penelitian menggunakan metode deskriptif analisis dan studi pustaka.Pada penelitian ini data terkumpul berupa kalimat imperatif dan beberapa tanggapan yang diberikan, karena dalam kalimat imperatif selalu mengharapkan adanya reaksi dari lawan tutur. Hasil penelitian menunjukkan bahwa kalimat imperatif terdapat lima, yaitu kalimat perintah biasa, kalimat perintah permintaan, kalimat perintah ajakan, kalimat perintah, kalimat perintah suruhan, dan kalimat perintah larangan.
\end{abstract}

Kata kunci: kalimat imperatif, bahasa Dayak Deah

\section{PENDAHULUAN}

Sistem kebahasaan yang ada di dunia ini memiliki keuniversalan. Artinya dalam setiap bahasa memiliki beberapa unsur yang sama,dalam hal struktur kalimat ataupun keberagaman kalimat. Bahasa Dayak Deah merupakan bahasa daerah yang memiliki kekhasan sendiri bagi penuturnya yang dijadikan sebagai lambang identitas masyarakat tutur Dayak Deah yang sudah dialihkan dari generasi ke generasi sebagai bahasa ibu.Bahasa Dayak Deah adalah bahasa yang dituturkan oleh hampir sebagian besar masyarakat yang ada di Desa Pangelak Kecamatan Upau Kabupaten Tabalong. Bahasa dayak deah digunakan untuk untuk berkomunikasi dan berinteraksi sosial di lingkungan masyarakat Dayak Deah. Masyarakat Dayak Deah menjadikan bahasa Dayak Deah sebagai bahasa ibu atau bahasa pertama.

Manusia sebagai makhluk sosial senantiasa berinteraksi dengan sesamanya dengan menggunakan bahasa.Oleh sebab itulah, kita mengenal adanya masyarakat bahasa. Menurut Chaer 
(2010:59), masyarakat bahasa adalah sekelompok orang yang merasa menggunakan bahasa yang sama. Jadi, dapat dikatakan bahwa orang/penutur yang sama menggunakan bahasa Dayak Deah maka dapat dikatakan sebagai masyarakat bahasa Dayak Deah.

Salah satu fungsi bahasa ialah sebagai alat komunikasi antara anggota masyarakat dan sebagai kontrol sosial.Bahasa sebagai fungsi alat komunikasi antara anggota masyarakat tersebut digunakan dalam berbagai lingkungan, tingkatan, dan kepentingan yang beraneka ragam dan kontrol sosial yang berfungsi mengendalikan komunikasi agar orang yang terlibat dalam komunikasi dapat saling memahami.Masing-masing mengamati ucapan, perilaku, dan simbol-simbol lain yang menunjukan arah komunikasi.Bahasa Dayak Deah ini kebanyakan digunakan oleh penuturnya dalam lingkungan keluarga di rumah dan dalam pergaulan sehari-hari.

Bahasa Dayak Deah merupakan bahasa daerah yang memiliki kekhasan sendiri bagi penuturnya yang dijadikan sebagai lambang identitas masyarakat tutur Dayak Deah yang sudah dialihkan dari generasi ke generasi sebagai bahasa ibu.Bahasa Dayak Deah adalah bahasa yang dituturkan oleh hampir sebagian besar masyarakat yang ada di Desa Pangelak Kecamatan Upau Kabupaten Tabalong. Bahasa Dayak Deah digunakan untuk untuk berkomunikasi dan berinteraksi sosial di lingkungan masyarakat Dayak Deah.

Sistem bahasa yang ada di dunia ini memiliki keuniversalan. Artinya dalam setiap bahasa memiliki beberapa unsur yang sama,dalam hal struktur kalimat ataupun keberagaman kalimat. Dalam penelitian ini akan menfokuskan pada struktur kalimat dalam bahasa Dayak Deah, yaitu kalimat imperatif.

Kalimat memiliki fungsi penting dalam komunikasi dan interaksi dengan lawan tutur. Penutur dalam berkomunikasi dengan lawan tutur memperhatikan pilihan kalimat agar lawan tutur bisa menangkap apa yang ingin kita sampaikan. Oleh sebab itu.wujud kalimat lisan dan tulisan memiliki perbedaan. Wujud kalimat lisan, kalimat diucapkan dengan memperhatikan nada suara, yaitu naik keras, jeda (pemberhentian), dan diakhiri dengan intonasi, sedangkan wujud tulisan biasanya diawali dengan huruf capital dan dikhiri dengan intonasi glotal yaitu tanda titik (.), tanda seru (!), dan tanda tanya (?).salah satu fungsi kalimat adalah memerintah atau meminta lawan tutur untuk melakukan sesuatu seperti yang dimaksudkan oleh penutur. Salah satu jenis kalimat tersebut adalah kalimat imperatif. 
Kalimat imperatif adalah sebuah kalimat yang mengandung maksud memerintah atau meminta suatu hal kepada orang lain, dengan tujuan agar orang lain tersebut menuruti permintaan yang diminta oleh peminta. Kalimat imperatif memiliki berbagai jenis, a) kalimat imperatif biasa, b) kalimat imperatif, c) kalimat imperatif pembeian izin, d) kalimat imperatif ajakan dan e) kalimat imperatif suruhan (Rahardi, 2006:79). Kalimat imperatif yang dikemukakan oleh Alwi, dkk (2003:353) sebagai berikut.

a. Perintah atau suruhan biasa jika pembicara menyuruh lawan bicaranya berbuat sesuatu;

b. Perintah halus jika pembicara tampaknya tidak memerintah lagi, tetapi menyuruh mencoba atau mempersilakan lawan bicara sudi berbuat sesuatu;

c. Permohonan jika pembicara, demi kepentingannya, mitra lawan bicara berbuat sesuatu;

d. Ajakan dan harapan jika pembicara mengajak atau berharap lawan bicara berbuat sesuatu;

e. Pembiaraan jika pembicara minta agar jangan dilarang.

Kalimat imperatif dalam bahasa Dayak Deah sangat beragam jenisnya, bisa saja berisi kalimat perintah yang keras dan kasar, dan bisa juga berupa kalimat perintah dengan permohonan yang santun dan halus. Selain dua hal itu dalam kalimat imperatif juga berisi larangan terhadap suatu hal atau membiarkan seseorang melakukan suatu hal.Kalimat imperatif yang diucapkan secara lisan oleh penutur dengan nada tinggi jika dibuat dalam kalimat akan diakhiri dengan penggunaan tanda seru pada akhir kalimat. Begitu pula dengan kondisi yang lain, kalimat ini memiliki banyak intonasi pengucapan sesuai dengan bentuk imperatif yang ingin disampaikan oleh penutur.

Dalam penggunaanya.Masyarakat Dayak Deah sering menggunakan kalimat perintah baik di rumah, sekolah atau lingkungan masyarakat.Baik itu ajakan, larangan atau permohonan.Kalimat imperatif yang ada dalam bahasa Dayak Deah ini memiliki fungsi yang beragam, sehingga menarik untuk diteliti lebih jauh. Tujuan dari penelitian ini adalah untuk mendeskripsikan dan mengidentifikasi wujud kalimat imperatif dalam bahasa Dayak Deah.

\section{METODE}

Pendekatan yang digunakan adalah pendekatan kualitatif. Hal ini karena pendekatan kualitatif diharapkan mampu menghasilkan suatu uraian tentang ucapan, tulisan, dan perilaku yang dapat diamati/dilihat dari suatu individu, kelompok, dan masyarakat.Bodgan dan Taylor (dalam Moleong, 
2010:4) mendefinisikan metodologi kualitatif sebagai prosedur penelitian yang menghasilkan data deskriptif berupa kata-kata tertulis atau lisan dari orang-orang atau perilaku orang yang dapat diamati. Penelitian deskriptif pada umumnya dilakukan dengan tujuan utama, yaitu menggambarkan secara sistematis fakta dan karakteristik objek dan subjek yang diteliti secara tepat. Data yang terkumpul diklasifikasikan atau dikelompok-kelompokan menurut jenis, sifat, atau kondisinya, setelah datanya lengkap, kemudian dibuat kesimpulan.

Metode yang digunakan dalam penelitian ini adalah metode deskriptif analisis dan studi pustaka.Adapun metode deskriptif yang bertujuan untuk mengumpulkan, mengklarifikasi, dan menganalisis data sehingga diperoleh gambaran yang menyeluruh mengenai kalimat imperatif dalam bahasa Dayak Deah. Pada penelitian ini data terkumpul berupa kalimat imperatif dan beberapa tanggapan yang diberikan, karena dalam kalimat imperatif selalu mengharapkan adanya reaksi dari lawan tutur.

\section{PEMBAHASAN}

Kalimat imperatif adalah kalimat yang memberi perintah, komando atau larangan. Singkatnya definisi kalimat imperatif adalah kalimat perintah. Dalam kalimat bahasa Dayak Deah juga terdapat kalimat imperatif yang bertujuan untuk meminta seseorang melakukan sesuatu tindakan atau mengikuti harapan dari penutur.Tetapi ada pula yang bertujuan agar seseorang tidak melakukan suatu tindakan.Pada bahasa Dayak Deah, terdapat beberapa ciri tambahan yang menandakan bahwa suatu kalimat tersebut merupakan kalimat imperatif dalam bahasa Dayak Deah.Wujud kalimat imperatif yang terdiri dari kalimat imperatif biasa, kalimat imperatif permintaan, kalimat imperatif ajakan, kalimat imperatif suruhan, dan kalimat imperatif larangan.

Kalimat imperatif memiliki ciri formal, seperti berikut.

1. Intonasi yang ditandai nada rendah di akhir tuturan.

2. Pemakaian partikel penegas, penghalus, dan kata tugas ajakan, harapan, permohonan, dan larangan.

3. Susunan inversi sehingga urutannya menjadi tidak selalu terungkap predikat-subjek jika diperlukan,

4. Pelaku tindakan tidak selalu terungkap.

Berdasarkan hasil klasifikasi wujud kalimat imperatif dalam bahasa lisan Dayak Deah, meliputi wujud dan klasifikasi kalimat imperatif.Data pada penelitian ini berupa tuturan masyarakat Dayak Deah yang diambil dari kalimat lisan dari setiap keluarga, antar tetangga, kegiatan sosial, tempat 
ibadah.Wujud kalimat imperatif yang terdiri dari kalimat imperatif biasa, kalimat imperatif permintaan, kalimat imperatif ajakan, kalimat imperatif suruhan, dan kalimat imperatif larangan.

Hasil dari klasifikasi kalimat imperatif dalam bahasa lisan, pada tahap ini analisis data terdapat kalimat imperatif biasa yang ditandai dengan penanda kata seru (!), kalimat imperative permintaan yang ditandai dengan penanda kata mohon(mohon) atauminta (tindu), kalimat imperatif ajakan yang ditandai dengan penanda kata ayo(ayu), coba (cuba), mari (pitu), kalimat imperatif suruhan yang ditandai dengan penanda kata ayu (ayo), noon (biar), dan cuba (coba), kalimat imperatif larangan yang ditandai dengan penanda kata jangan (ai).

\section{a. Kalimat Imperatif Biasa}

Kalimat perintah biasa adalah kalimat perintah yang isinya memuat perintah secara langsung untuk melakukan sesuatu.Kalimat ini sering digunakan dalam percakapan sehari-hari secara lisan. Kalimat imperatif biasa memiliki ciri-ciri, a) berintonasi keras, b) didukung dengan kata kerja dasar, dan 3) berpatikel pengeras -deh (-lah). Berikut tindak tutur kalimat perintah biasa yang dituturkan oleh penutur kepada mitra tutur.

1) Tolop jaongne!

2) Sinop!

3) Umpi deh parek sio!

4) Tungoh ba kursi itu erai erai!

Situasi tuturan:

Dituturkan oleh seorang panitia kepada para jemaah sebelum mengikuti ibadah di Gereja, demi kenyamanaan bersama.

Analisis:

Tuturan di atas, termasuk dalam kalimat perintah yang isinya salah satu panitia memohon kepada jemaah agar menjaga ketertiban dan kebersihan di tempat ibadah.

\section{b. Kalimat Imperatif Permintaan}

Bentuk kalimat ini merupakan kalimat perintah, yang isinya memohon kepada mitra tutur agar mau melaksanakan apa yang diperintahkan oleh sang penutur. Kalimat seperti itu ditandai 
oleh kata $t i n d u$ (minta) atau mohon. Subjek pelaku kalimat imperatif permintaan ialah pembicara yang sering tidak dimunculkan. Berikut tindak tutur kalimat perintah permintaan yang dituturkan oleh penutur kepada mitra tutur.

1). Tindu, maaf deh!

(Minta, maaf ya!)

2). Mohon, sumbangan sukarela.

(Mohon, sumbangan sukarela.)

Situasi tuturan:

Dituturkan oleh seorang kakak kepada adiknya, karena si kakak merasa bersalah. Analisis:

Tuturan (1), termasuk dalam kalimat perintah yang isinya meminta kepada mitra tutur agar mau memaafkan.

\section{c. Kalimat Imperatif Ajakan}

Kalimat perintah ajakan adalah kalimat yang mengandung makna ajakan agar mitra tutur mau mengikuti apa yang dikehendaki oleh sang penutur. Tuturan ditandai dengan adanya kata ajakan.Ciri lainyang dimiliki kalimat imperatif dalam bahasa Dayak Deah adalah adanya atau diberikannya kata penunjuk perintah seperti "ayu", "cuba", "pitu”. Dengan tujuan orang atau objek yang dituju mampu mengikuti harapan dari penutur.Berikut adalah tindak tutur kalimat perintah ajakan yang dituturkan oleh penutur kepada mitra tutur.

1) Ayu, taam kerja bakti mih lingkungan ne barasih!

(Ayo, kita kerja bakti biar lingkungan ini bersih!)

2) Ayu, laju!

(Ayo, cepat!)

3) Cuba, iko pitu dile!

(Coba,kamu kesini dulu!)

4) Pitu, riet aku tungoh!

(Mari, duduk dekat aku!) 


\section{5) Pitu, taam kumant!}

(Mari, kita makan!)

Situasi tuturan (1) :

Dituturkan oleh seorang Bapak-bapak mengajak kepada rekannya untuk kerja bakti di lingkungan sekitar agar terciptanya lingkungan yang sehat dan bersih.

Analisis:

Tuturan (1), termasuk dalam kalimat perintah yang isinya meminta kepada mitra tutur agar saling gotong royong untuk membersihkan lingkungan sekitar.

Situasi tuturan (5) :

Tuturan ini terjadi di dalam ruang makan pada sebuah keluarga ,orang yang satu mengajak orang yang lain untuk makan bersama.

\section{d. Kalimat Imperatif Suruhan}

Kalimat suruh yang sebenarnya ditandai oleh pola intonasi suruh. Selain itu apabila predikatnya terdiri dari kata verbal intrasitif. Bentuk kata verbal itu tetap, partikel -lah dapat ditambahkan pada kata verbal itu untuk menghaluskan perintah. subjeknya yang berupa persona kedua bisa ada bisa juga tidak.

Kalimat imperatif suruhan biasanya digunakan bersama penanda atau dengan kata ауи (ayo), noon (biar-lah), dan cuba (coba).dapat diartikan bahwa kalimat itu menyuruh membiarkan supaya sesuatu terjadi atau berlangsung. Dalam perkembangannya kemudian pembiaran berarti minta izin agar sesuatu jangan dihalangi.

1. Tungoh!

(Duduk!)

2. Cuba pinda ba ombo lemari!

(Coba lihat di atas lemari)

3. Noon poh ise kant tulak ponoh!

(Biarlah dia pergi lebih awal) 


\section{e. Kalimat Impertif Larangan}

Kalimat larangan ditandai penggunaan kata Deah dalam bahasa Dayak Deahyang artinya jangan di awal kalimat atau. Partikel -lah atau dalam bahasa dayak deah partikel deh dapat ditambahkan pada kalimat tersebut untuk memperhalus kalimat.Berikut tindak tutur kalimat larangan yang dituturkan oleh mitra tutur.

1. Ai waoit mbuli buku so!

(Jangan dibawa pulang buku itu!)

2. Ai mara!

(Jangan, marah!)

3. Ai pe denan deh!

(Jangan, ke sana ya!)

4. Ai ngupi parek sembarangan deh!

(Janganlah, membuang sampah di sembarang tempat!)

Situasi tuturan:

Dituturkan oleh seorang kakak kepada adiknya yang ingin membawa buku cerita kepunyaan kakaknya.

Analisis:

Tuturan (1), termasuk dala kalimat larangan yang isinya melarang dengan kata tegas kepada mitra tutur agar tidak membawa buku apa yang diperintahkan oleh sang tutur.

\section{SIMPULAN}

Kalimat imperatif atau kalimat perintah adalah kalimat berfungsi untuk meminta atau melarang seseorang untuk melakukan sesuatu.Pada bahasa Dayak Deah, terdapat beberapa ciri tambahan yang menandakan bahwa suatu kalimat tersebut merupakan kalimat imperatif dalam bahasa Dayak Deah.Wujud kalimat imperatif yang terdiri dari kalimat imperatif biasa, kalimat imperatif permintaan, kalimat imperative ajakan, kalimat imperatif suruhan, dan kalimat imperatif larangan.

Kalimat imperatif biasa memiliki ciri-ciri, a) berintonasi keras, b) didukung dengan kata kerja dasar, dan 3) berpatikel pengeras -deh (-lah). Bentuk kalimat ini merupakan kalimat perintah, yang 
isinya memohon kepada mitra tutur agar mau melaksanakan apa yang diperintahkan oleh sang penutur. Kalimat seperti itu ditandai oleh kata tindu(minta) atau mohon. Kalimat imperative ajakan dalam bahasa Dayak Deah memilikiciri, yaitu adanya atau diberikannya kata penunjuk perintah seperti “ayu”, “cuba”, “pitu”. Kalimat imperatif suruhan biasanya digunakan bersama penanda atau dengan kata ayu (ayo), noon (biar), dan cuba (coba). Kalimat larangan ditandai penggunaan kata Deah dalam bahasa Dayak Deahyang artinya jangan di awal kalimat atau. Partikel -lah atau dalam bahasa dayak deah partikel -deh dapat ditambahkan pada kalimat tersebut untuk memperhalus kalimat.

\section{SARAN}

Dengan adanya penelitian dapat dijadikan sebagai bahan ajar bahasa daerah di sekolah-sekolah khususnya di daerah Tabalong, Kalimantan Selatan.Bagi peneliti lain yang berminat meneliti pembahasan kalimat ini disarankan agar cakupan diperluas lagi, sehingga hasil penelitian akan menjadi lebih bervariasi dan tentunya akan menambah khasanah di bidang ilmu lainnya khususnya dalam kajian sintaksis bahasa Dayak Deah.

Dalam berbahasa, baik secara lisan maupun tulis, kita sebenarnya tidak mengunakan kata-kata secara lepas. Akan tetapi, kata-kata itu terangkai mengikuti aturan atau kaidah yang berlaku sehingga terbentuklah rangkaian kata yang dapat mengungkapkan gagasan, pikiran, atau perasaan. Rangkaian kata yang dapat mengungkapkan gagasan, pikiran, atau perasaan itu dinamakan kalimat.

\section{DAFTAR RUJUKAN}

Alwi, H. dkk. Tata Bahasa Baku Bahasa Indonesia. Jakarta: Pusat Bahasa dan Balai Pustaka.

Arifin, E. Zaenal dan Junaiyah.2009. Sintaksis. Jakarta: Grasindo.

Chaer, A.. 2015. Sintakasis Bahasa Indonesia: Pendekatan Proses. Jakarta: Rineka Cipta.

Chaniago, S. M., dkk. 2001. Pragmatik . Jakarta: Universitas Terbuka.

Kusno, A. 2014. Kesantunan Linguistik Kalimat Imperatif oleh Guru dan Pengasuh kepada Anak Didik di Taman Penitipan Anak (TPA) Sanggar Rubinha Samarinda. JBSP Jilid 4 Nomor 2 Oktober 2014 (Hlm.149-162)

Nadar, F.X. 2009. Pragmatik dan Penelitian Pragmatik. Yogyakarta: Graha Ilmu.

Putrayasa, I. B. 2010. Analisis Kalimat: Fungsi Kategori dan Peran. Bandung: Refika Aditama. 
Rahardi, R. K. 2005. Pragmatik Kesantunan Imperatif Bahasa Indonesia.Jakarta: Erlangga.

Tarmini, 2013. Sintaksis Bahasa Indonesia. Bandar Lampung: Universitas Lampung. 